Volume: 11 Issue: 1 Year: 2014

\title{
Measurement of efficiency of fiscal policies implemented for global crisis: Did Turkey have success in crisis management?
}

\author{
Coşkun Karaca ${ }^{1}$ \\ Erginbay Uğurlu ${ }^{2}$
}

\begin{abstract}
Even if fiscal policy measures of countries show similarities, these measures have an important role in depth of recession and depression, reestablishment of market confidence and determination of the duration of economic recovery together with stability and elasticity of domestic financial and economic system. In the study, the effects of fiscal policies, which were implemented in Turkey during global crisis, on growth trend of the country in the period of crisis were examined. The effects of fiscal policy shocks on national income were examined through structural VAR system by using the data of the period of 2006-2012 and it was seen that the effects of net tax income and public expenditures in the model on growth was positive. On the basis of empirical findings of the study, it can be said that fiscal policies which were implemented in Turkey during last global crisis partially have growth-increasing effect.
\end{abstract}

Keywords: global crisis; fiscal policies; structural VAR; crisis management

\section{Introduction}

Fluctuations in financial markets which begin in mid-2007 with repayment problems in USA mortgage loans became a global financial crisis by deepening as of September 2008. Problems in financial system and uncertainty affected investor and consumer confidence negatively and in many countries domestic and foreign demand declined, so production in these countries decreased. Global crisis also affected Turkey which has commercial and financial relations with whole world. Growth and employment rates of Turkey declined in parallel with both shrinking foreign and

\footnotetext{
1 Assistant Prof. Dr., Cumhuriyet University, Faculty of Economics and Administrative Sciences, Department of Public Finance, Sivas, Turkey. coskunkaraca@hotmail.com

2 Assistant Prof. Dr., Hitit University, Faculty of Economics and Administrative Sciences, Department of Economics, Corum, Turkey. erginbavugurlu@hitit.edu.tr
} 
Karaca, C.., \& Uğurlu, E. (2014). Measurement of efficiency of fiscal policies implemented for global crisis: Did Turkey have success in crisis management? International Journal of Human Sciences, 11(1), 920-947. doi: $\underline{10.14687 / \text { ijhs.v11i1.2867 }}$

domestic demand, and manufacturing industry production which the leading sector of economy and capacity utilization rate decreased.

After these processes, Turkey implemented rarely encountered fiscal policies for financial markets and real sector in order to remove the effects of crisis and to restore economic stability. Even though there are some different opinions about the efficiency of implemented policies it can be said that policies which were implemented before and after crisis have an important role in reducing the effects of crisis.

In '2011 Progress Report' released by the European Commission in October 2011, crisis resolution strategies of Turkish economy was mentioned and it was stated that Turkey performed fiscal policies in a successful way during crisis. It was emphasized in the report that although Turkey was negatively affected by global financial crisis, it again reached strong growth performance quickly as a result of the previously adopted supervisory and regulatory reforms. Additionally, it was stated that strong recovery in the economy brought about considerable decline in unemployment rate ${ }^{3}$.

This article examines the effects of tools which were used by the government to struggle with crisis on the economy in order to measure efficiency of fiscal policies which were implemented in Turkey during global economic crisis. Expenditure and tax reduction packages which were enacted by the government after crisis whose effects concretely increased as of the third quarter of 2008 aimed at the remove of insufficiency of demand and confidence crisis emerging in real sector and households. In the first part of the study, the effects of crisis on Turkish economy's indicators such as economic growth, consumption, unemployment, payments and budget balance which were selected from finance and public finance areas. In the second part, an empirical literature examination which shows the effects of implemented fiscal policies on real economy was held and in the last part the effects of main indicators relating to fiscal policies implemented during crisis on industrial production was aimed to be estimated empirically.

\section{The Effects of Crisis on Turkey and Implemented Fiscal Policy Measures}

\subsection{The Effects of Crisis on Turkey}

Countries' degree of exposure to global crisis varies depending on both existing economic structures and policies implemented to overcome the crisis. The government stuck to fiscal

\footnotetext{
3 It was stated by the Commission that the economy could not precisely benefit from economic recovery since adjustments were insufficient, in order to decrease the risks about positive and negative scenarios some measures should be taken such as fiscal transparency should be improved, monetary and fiscal policies should be adju sted to current conditions, the actions to target inflation and to protect the stability should be increased. For detailed information see European Commission, 2011 Turkey Progress Report, SEC (2011) 1201, Brussels.
} 
Karaca, C.., \& Uğurlu, E. (2014). Measurement of efficiency of fiscal policies implemented for global crisis: Did Turkey have success in crisis management? International Journal of Human Sciences, 11(1), 920-947. doi: $\underline{10.14687 / \text { ijhs.v11i1.2867 }}$

discipline after 1999 and 2001 crises, banking system did not have huge open positions differently from 2001 crisis period and banks had strong capital structures, so these situations provide a strong position for Turkey in order to overcome the crisis. Additionally, it can be said that demand shrinking which arises from negative future expectations and confidence crisis was aimed to be removed through fiscal policy decisions and that it was achieved to some extent.

When seeing main economic indicators of Turkey during the crisis, it can be said that 2008 is starting year, 2008 is the year in which crisis is most effective on Turkey and 2010 is the year in which the effects of crisis began to decrease. This statement is supported by the situation that Turkish economy grew by $0,7 \%$ in 2008, shrank by $4,8 \%$ in 2009 because of the effects of crisis, and in 2010 and 2011 it grew by $9,2 \%$ and $8,8 \%$ respectively. Negative situation in growth rate of 2009 reflected in unemployment rate and unemployment rate which is $11 \%$ in 2008 reached $14 \%$ in 2009 with a sharp increase. Increase in unemployment rate slowed in the ensuing years and this rate was 11.9, 9.8 and 9.2 for the years of 2010, 2011 and 2012 respectively.

The situation of foreign trade indicators are similar economic growth and unemployment rate and export volume which increased by $23.1 \%$ in 2008 shrank by $22.6 \%$ in 2009 . In the same period, import also decreased and while it increased by $18.8 \%$ in 2008, it decreased by $30.2 \%$ in 2009 . Current account balance as a percentage of gross domestic product (GDP) decreased and it became $2.2 \%$ in 2009 while it was $5.6 \%$ in 2008 .

Table 1. Main Economic Indicators in Turkey during the Crisis

\begin{tabular}{|c|c|c|c|c|c|c|}
\hline & 2007 & 2008 & 2009 & 2010 & 2011 & 2012 \\
\hline \multicolumn{7}{|l|}{ Domestic Product (growth rate) } \\
\hline Real GDP & 4.7 & 0.7 & -4.8 & 9.2 & 8.8 & 2.2 \\
\hline Private Consumptions & 5.5 & -0.3 & -2.3 & 6.7 & 7.7 & -0.6 \\
\hline Investments & 3.1 & -6.2 & -19.0 & 30.5 & 18.0 & -2.7 \\
\hline \multicolumn{7}{|l|}{ Public Finance (as $\%$ of GDP) } \\
\hline Income & 22.6 & 22.1 & 22.6 & 23.1 & 22.9 & 23.4 \\
\hline Expenditure & 24.2 & 23.9 & 28.2 & 26.8 & 24.2 & 25.5 \\
\hline Budget Balance & -1.6 & -1.8 & -5.6 & -3.7 & -1.3 & -2.1 \\
\hline Central Government Total Debt & 39.6 & 40.0 & 46.3 & 43.1 & 40.0 & 37.6 \\
\hline Public Sector Borrowing Requirement & 0 & 2 & 5 & 2 & 0 & 1 \\
\hline \multicolumn{7}{|l|}{ Other Indicators } \\
\hline Current Account Balance/GDP & -5.9 & -5.7 & -2.3 & -6.4 & -10.0 & -6.1 \\
\hline Capacity Utilization Rate (\%) & 80.2 & 76.7 & 65.3 & 72.6 & 75.4 & 74.2 \\
\hline Unemployment Rate $(\%)$ & 10.3 & 11.0 & 14.0 & 11.9 & 9.8 & 9.2 \\
\hline
\end{tabular}

Source: Central Bank, 2012; TUIK, 2013.

In 2008 and 2009, an important disruption is seen in real GDP, consumption, investment, budget balance and unemployment rate; however decrease in import indicates a recovery in current account balance depending on decreasing consumption demand. It can be said that monetary 
Karaca, C.., \& Uğurlu, E. (2014). Measurement of efficiency of fiscal policies implemented for global crisis: Did Turkey have success in crisis management? International Journal of Human Sciences, 11(1), 920-947. doi: $\underline{10.14687 / \text { ijhs.v11i1.2867 }}$

policies implemented by Central Bank and stimulus packages enacted by the government have a role in the recovery of economic indicators and return of unfavorable economic condition to a positive condition in 2010 and 2011. However decreases in growth rate in given years and inconsistency in income and expenditures which arise from the crisis gave to the increases in budget deficit ${ }^{4}$. While total central government debt as \% of GDP was $1.6 \%$ and $1.8 \%$ in 2007 and 2008 respectively, it reached 5.6\% in 2009 in which crisis was most effective and interventions increased.

\subsection{Fiscal Policy Measures}

Global economic crisis which began in December 2007 and affected the whole world with USA is accepted as the longest and deepest economic stagnation experienced after the Great Depression in 1930s (Leeper et al., 2010: 1000). So the interventions aiming to overcome the crisis should comprise of convenient policies with the depth of the crisis. In the beginning periods of the crisis, especially the governments of developed countries quickly adopted stability policies. The first response of these countries was to implement monetary policies which contain interest rate cuts. However since asset prices decreased sharply and central bank maintained its extraordinary implementation which allows illiquid asset expansion, rigid measures should be taken in order to cease downward trend in the economy (Frenkel and Rapetti, 2009: 696). Thus many countries in the world implemented fiscal policies containing substantial expenditure and tax cuts in order to stimulate domestic markets. In USA where the crisis emerged, only the policies implemented by Congress of the United States consisted of 780 billion dollar stimulus packages ${ }^{5}$. With this policy, US government created a strategy to overcome the crisis by increasing expenditures and decreasing tax cuts differently from policies implemented in previous years. About two-third of stimulus package consisted of government expenditures and transfers (Congressional Budget Office, 2009). Especially, when infrastructure expenditures are compared with the expenditures in previous 30 years, the importance of government interventions in providing economic stability and stimulation of total demand was opened to be discussed again.

In the fiscal policy which aims to overcome stagnation, public expenditures are raised in order to increase total demand and tax cuts are applied. While increasing public expenditures raise national

\footnotetext{
4 When current and investment expenditures and expenditures relating to current and capital transfers during crisis period are removed from seasonal effects, it is seen that it is at constant level. So it can be said that budget deficit aris es from stagnation rather than increase in expenditures.

${ }^{5}$ It is estimated that American Recovery and Reinvestment Act (ARRA) of 2009 created a 720 billion dollars additional incentives between 2009 and 2011 fiscal years and these incentives are about 5 percent of 2009 GDP. Additionally, it is estimated that costs of Economic Stimulus Act of 2008 and Worker, Homeownership, and Business Assistance Act of 2009 which are acknowledged as out of ARRA are totally 190 billion dollars (See Leeper et al., 2010: 1000).
} 
Karaca, C.., \& Uğurlu, E. (2014). Measurement of efficiency of fiscal policies implemented for global crisis: Did Turkey have success in crisis management? International Journal of Human Sciences, 11(1), 920-947. doi: $\underline{10.14687 / \text { ijhs.v11i1.2867 }}$

income level and employment depending on marginal propensity to consume, purchasing power is wanted to be increased with respect to the type of tax cut and real sector output is aimed to be increased. In this regard, Turkey's fiscal policy measures during the crisis which can be seen in extraordinary periods aim to remove uncertainty and confidence crisis which emerge in the market and to compensate demand shrinking which arises from the decrease in real sector investments and household consumption expenditures. Since the years of Great Depression, many economists including Keynes have stated that the interventions of governments to the economy during stagnation periods mainly aim to create additional business fields by increasing total demand especially in the short term (Romer and Bernstein, 2009: 2; Ramey, 2012: 1), because market mechanism itself cannot solve unemployment problem during these periods. In stagnation periods, it can be a rational decision that an employer whose stocks increases and profitability decreases fires his employees by behaving as a homo economicus. However if many employers fire his employees and the number of unemployed persons exceeds a certain level, emergence of negative cycle becomes an inevitable situation, because each of unemployed person means further total demand shrinking as asserted in Keynesian economic theory. New shrinking in demand gives rise to new severances, new severances give rise to new demand shrinking, so this situation causes an everdeepening negative cycle. It is clear that this self-feeding cycle goes to collapse. The main reason of unemployment which emerges in stagnation periods is insufficient total demand. Hence the government should take incentive measures to stimulate the demand and decrease labor cost in real sector in order to prevent severances until recovery in the economy begins. Tax expenditures emerging when such a policy which aims to decrease labor costs of employers is implemented will be probably less than tax expenditures emerging in an opposite situation (Erdogdu, 2010: 338). So fiscal policies implemented especially in stagnation periods are effective tools in removal of contractionary pressures of the crisis (Frenkel and Rapetti, 2009: 696).

Owing to the considerable decrease in public debt due to public finance discipline in the period of 2002-2007, Turkish government can take expansionary fiscal measures which may lessen the effects of global crisis even if these measures are limited. In this regard, in order to stimulate demand, special consumption tax (ÖTV) and value-added tax (KDV) were decreased and so firms could deplete their stocks, some investment incentives adopted in order to enhance investment climate and premium support systems are created in order to prevent severances. Additionally, research and development $(\mathrm{R} \& \mathrm{D})$ supports which may increase competitiveness in foreign market were provided, credit and guaranty supports were provided to SME (Small and medium enterprises) and exporting companies. It can be said the law no 5838 and cabinet decision no 14802 which were put 
Karaca, C.., \& Uğurlu, E. (2014). Measurement of efficiency of fiscal policies implemented for global crisis: Did Turkey have success in crisis management? International Journal of Human Sciences, 11(1), 920-947. doi: $\underline{10.14687 / \text { ijhs.v11i1.2867 }}$

into effect in 2009 by the government contains the most extensive incentive measures which were implemented during crisis. These incentives focused on increasing the household consumption and attempted to affect input costs of real sector. It can be said that implementations aiming at decreasing costs in consumer loans and real estate sector through special consumption tax (ÖTV) and value-added tax (KDV) cuts which were adopted with cabinet decision no 14802 in 2009 have a huge impact on the stimulation of consumer demand. Reduced corporate tax measures implemented with the law no 5838 in February 2009; income tax withholdings and employer's national insurance contribution support provided an increase in productions and investments of real sector. Some important incentives relating to measures taken by government are seen in Table 2.

\section{Table 2. Fiscal Measures Taken Against the Crisis}

\begin{tabular}{|c|c|c|}
\hline Measure & Implementation & Explanation \\
\hline \multirow{8}{*}{$\begin{array}{l}\text { Taxational } \\
\text { Measures }\end{array}$} & Repatriation of Capital ${ }^{a}$ & $\begin{array}{l}\text { It contains tax cuts and exemptions in order to transfer assets abroad to } \\
\text { the country (Turkey). }\end{array}$ \\
\hline & $\begin{array}{r}\text { Private consumption tax } \\
\text { cuts }^{\text {b }} \\
\text { (up to } 15.06 .2009 \text { ) } \\
\end{array}$ & $\begin{array}{l}\text { Discounts were made in PCT which are collected from motor vehicles }{ }^{c} \text {. } \\
\text { Tax on white goods were discounted from } 6,7 \% \text { to } 0 \% \text {. }\end{array}$ \\
\hline & $\begin{array}{r}\text { Value-added tax cut (up } \\
\text { to } 30.09 .2009)\end{array}$ & $\begin{array}{l}\text { Tax on furniture and computer were discounted from } 18 \% \text { to } 8 \% \text {. } \\
\text { Tax on sales of home which is bigger than } 150 \mathrm{~m}^{2} \text { were discounted from } \\
18 \% \text { to } 8 \% \text {. }\end{array}$ \\
\hline & Stodk Earnings & $10 \%$ Stoppage on domestic investors were decreased to 0. \\
\hline & Tax Debt Deferral & Tax debts were split into 18 installments with $3 \%$ interest. \\
\hline & $\begin{array}{r}\text { Resource Utilization } \\
\text { Support Fund } \\
\end{array}$ & $\begin{array}{l}\text { Cut rates in loans provided to real persons were decreased from } 15 \% \text { to } \\
10 \% \text {. }\end{array}$ \\
\hline & $\begin{array}{r}\text { Special Communication } \\
\text { Tax (SCT) }\end{array}$ & SCT were decreased from $15 \%$ to $5 \%$. \\
\hline & SME Mergers & $\begin{array}{l}\text { If SMEs which merge until } 31.12 .2009 \text { can provide legal conditions, they } \\
\text { can profit from corporate tax exemptions and reduced corporate tax up } \\
\text { to } 75 \% \text {. }\end{array}$ \\
\hline \multirow{8}{*}{$\begin{array}{l}\text { Employment } \\
\text { Measures }\end{array}$} & $\begin{array}{r}\text { Short-time working } \\
\text { subsidy }\end{array}$ & $\begin{array}{l}\text { The amount of subsidy was increased by } 50 \% \text { and duration of utilization } \\
\text { increased from } 3 \text { months to } 6 \text { months. }\end{array}$ \\
\hline & $\begin{array}{r}\text { Young and Women } \\
\text { Employment }\end{array}$ & $\begin{array}{l}\text { Duration of incentive of Young and Women Employment was } \\
\text { increased. }\end{array}$ \\
\hline & $\begin{array}{r}\text { Unemployment } \\
\text { Insurance Benefits }\end{array}$ & It was increased by $11 \%$. \\
\hline & working schedule & Direct employment chance for 120000 unemployed people. \\
\hline & $\begin{array}{r}\text { Vocational Training } \\
\text { Programs }\end{array}$ & $\begin{array}{l}\text { In the program } 200000 \text { people will be trained and during the process in } \\
\text { which skills of labor force will be enhanced } 15 \mathrm{TL} \text { payments will be } \\
\text { made for each person. }\end{array}$ \\
\hline & $\begin{array}{r}\text { Entrepreneurship and } \\
\text { Education Advisory }\end{array}$ & $\begin{array}{l}\text { KOSGEB will denote } 4000 \mathrm{TL} \text { to the presented projects after } \\
\text { entrepreneurship education of unemployed people. }\end{array}$ \\
\hline & $\begin{array}{r}\text { Intern Education } \\
\text { Supports }\end{array}$ & $\begin{array}{l}15 \text { TL payments will be made to inexperienced people who graduated } \\
\text { from vocational high school or similar schools during the education } \\
\text { program. }\end{array}$ \\
\hline & $\begin{array}{r}\text { Additional Employment } \\
\text { Incentive }\end{array}$ & $\begin{array}{l}\text { Premium support will be provided to the investors who provide } \\
\text { additional employment. }(5084)\end{array}$ \\
\hline \multirow[t]{2}{*}{$\begin{array}{l}\text { Investment } \\
\text { Incentives }\end{array}$} & The Law No 5084 & $\begin{array}{l}\text { Through the law relating to investment and employment incentives, } \\
\text { income tax, insurance premium and energy supports were provided to } \\
\text { investors. }\end{array}$ \\
\hline & Regional Development & Corporate/Income tax cuts, employer's national insurance contribution \\
\hline
\end{tabular}


Karaca, C.., \& Uğurlu, E. (2014). Measurement of efficiency of fiscal policies implemented for global crisis: Did Turkey have success in crisis management? International Journal of Human Sciences, 11(1), 920-947. doi: $\underline{10.14687 / \text { ijhs.v11i1.2867 }}$

\begin{tabular}{|c|c|c|}
\hline & Support & $\begin{array}{l}\text { support, interest support, land assignment, value-added tax exemption, } \\
\text { duty exemption in accordance with the region. }\end{array}$ \\
\hline & R\&D Support & $\begin{array}{l}\text { In } 12 \text { sectors which need high technology and capital, and increase the } \\
\text { capacity of R\&D and technology, major project investments were } \\
\text { supported. }\end{array}$ \\
\hline & $\begin{array}{l}\text { Textile, Leather etc. } \\
\text { Sector Incentives }\end{array}$ & $\begin{array}{l}\text { Reduced corporate tax and employer's insurance premium support will } \\
\text { be provided to investors in accordance with the amount of employment } \\
\text { and region. }\end{array}$ \\
\hline \multirow{4}{*}{$\begin{array}{l}\text { Producer } \\
\text { and } \\
\text { Exporter } \\
\text { Incentives }\end{array}$} & SME Support & $\begin{array}{l}\text { Zero and low interest rate support, guarantee was provided to } 65 \% \text { of } \\
\text { loans which are given to SMEs within the context of Loan Guarantee } \\
\text { Support Implementation. }\end{array}$ \\
\hline & Export Incentive & Limit of export rediscounting credit was increased. \\
\hline & Agricultural Incentives & The maturity of low interest rate loans was extended. \\
\hline & Eximbank & Treasury total guarantee and loan limit increased to 4 billion dollars. \\
\hline \multirow{2}{*}{$\begin{array}{l}\text { R\&D } \\
\text { Incentives }\end{array}$} & Tax Cut & $\begin{array}{l}\text { Tax cut support provided to R\&D staffs were readjusted and support are } \\
\text { given to firms directly throughout } 5 \text { years. }\end{array}$ \\
\hline & Income Tax Cut & $\begin{array}{l}\text { Income tax on R\&D and supporting staffs were decreased in a certain } \\
\text { level }\end{array}$ \\
\hline
\end{tabular}

Source: Laws $(5811,5834,5838,5891,5904,5917)$ and council of ministers decisions (2008/14272, 2008/14489, 2009/14580, 2009/14593, 2009/15199,2009/14802,2009/14803, 2009/14804, 2009/14812,2009/14813, 2009/14881, 2009/15081,2009/15082, 2009/15199, 2009/15197, 2009/1) which were published in Official Journal.

a Duration of "Law No. 5811 on the Introduction of Some Assets to the National Economy" which is called as "Cash Repatriation Law" and adopted by being published in Official Journal of 22.11.2008 was enlarged and its scope was expanded

b Reduced rates which will expire on 15.06.2009 were enlarged through council of ministers decision on 16.06.2009 by determining different reduced rates.

c Reduced rates which were implemented until 15.06.2009 were as follows; rates were reduced from $37 \%$ to $18 \%$ on cars whose engine capacities are lower than $1600 \mathrm{~cm}^{3}$; from $10 \%$ to $1 \%$ on commercial box vans; from $4 \%$ to $1 \%$ on commercial flatbed vans; from $4 \%$ to $1 \%$ on tow trucks, midibuses, special-purpose vehicles and lorries; from $1 \%$ to $0 \%$ on buses; from $9 \%$ to $2 \%$ on minibuses; from $22 \%$ to $11 \%$ on motorcycles whose engine capacities are lower than $250 \mathrm{~cm}^{3}$.

As a result of reforms in financial sector which were regulated in 2009, financial structures of banks and banking regulatory and supervisory system were strengthened and so crisis less damaged the financial sector in Turkey. As can be seen in Table 2, all of the measures taken by the government during the crisis focused on support to real sector and prevention of severance. According to the results of income distribution surveys, the large part of the population in Turkey had income at minimum subsistence level or less, so policies aimed to protect purchasing power had an important role in stimulation of deferred domestic demand. Even if additional tax cuts relating to demand shrinking and real sector supports and increases in some expenditure (see Table 2) items reduced the negative impacts of deepening global crisis on economy, these measures affected financial performance of the government negatively and current account deficit considerably increased. According to calculations made by DPT (2009: 38), it is estimated that budgetary cost of income measures taken against crisis in the period of 2008-2010 is 5.9 billion TL; the cost of expenditure measures is 46.2 billion TL. It is estimated that costs of measures which do not have direct impact on the budget and measures which are oriented to crisis are 64.9 billion TL in total. 
Karaca, C.., \& Uğurlu, E. (2014). Measurement of efficiency of fiscal policies implemented for global crisis: Did Turkey have success in crisis management? International Journal of Human Sciences, 11(1), 920-947. doi: $\underline{10.14687 / \text { ijhs.v11i1.2867 }}$

\section{Literature Review on the Efficiency of Fiscal Policies}

Fiscal policy can be described as the use of tax, government transfers or government expenditures in the way of purchase of goods and services in order to change total demand curve (Krugman and Wells, 2006:296). There is a close relationship between appearance time of fiscal policy tools, and historically experienced economic stagnation and unemployment. Actually, 1929 Crisis has an impact on the emergence of Keynesian fiscal policy which formed the basis of modern fiscal policy idea with the aid of depression and unemployment. 1929 Crisis and huge increases in unemployment showed the whole world that automatic equilibrium mechanis $m$ which was asserted as prevalent in market economies does not work properly and unemployment and price fluctuations can be seen when there is no intervention to the market (Onder, 2012: 116). Keynes claimed that economy cannot find the balance automatically in such a period without huge social and economic devastations and he pointed out that interventions in economy are required in order to overcome crisis and these interventions can be made by the government (Erdogdu, 2010: 330).

Keynes stated that resource of the fluctuations in production is fluctuations in nominal total demand and he advocated that change in investment level which is an important component of total demand can return to a stable level through government intervention. Thus, the 'multiplier' which was used by Kahn to show the relationship between investment and employment level was used by Keynes to show the effect of an increase in investment expenditures on total demand. Multiplier effect which show in most instances that increases in expenditures creates increase in national income level presents a valid reason to increase public expenditures in the case of stagnation and unemployment. Multiplier coefficient notion which is used to measure the efficiency of fiscal policies especially in stagnation periods became subject to many studies relating to this issue. In this part, firstly the studies about multiplier coefficient which were obtained through mentioned studies will be examined and after that literature review will be carried out on the impacts of governments' tools such as tax cuts, transfer expenditures and borrowings on the economy.

\subsection{Multiplier Coefficient Relating to Government Expenditures}

In theory, government expenditures relating to purchases of goods and services have greater multiplier effect than tax cuts and transfer expenditures (IMF, 2008: 5). However, since optional fiscal policies are implemented in stagnation periods in which many factor have role, distinction of impacts of these policies on the economy get difficult and multiplier effect may change due to the instability of other policy tools. However, it is possible to obtain a few results about multiplier 
Karaca, C.., \& Uğurlu, E. (2014). Measurement of efficiency of fiscal policies implemented for global crisis: Did Turkey have success in crisis management? International Journal of Human Sciences, 11(1), 920-947. doi: $\underline{10.14687 / \text { ijhs.v11i1.2867 }}$

coefficient in light of studies in literature: i) multiplier coefficient may vary depending on type, continuity and financing method of government expenditures (Ramey, 2011a: 673); ii) there are both studies in which the value of multiplier coefficient is estimated between 0.5 and 1.5 (Ramey, 2012: 3), and studies which reach multiplier coefficient being smaller than zero and larger than 4 (IMF, 2008: 17); iii) there is no evidence about the fact that government investments multiplier is bigger than multiplier of government expenditures which are made by these investments; iv) while the effects of tax changes are less than the effects of changes in expenditures in the short term, this situation is not always in this manner in the medium term; v) multiplier coefficients are in tendency to be higher in large economies (IMF, 2008: 18).

Empirical studies which were carried out about multiplier coefficient of government expenditures in the countries generally used structural VAR and general equilibrium model. In the study of Leeper et al. (2010) about US economy in which data of recent global crisis period were also used, multiplier coefficient of government expenditures was calculated on the basis of the assumptions of neoclassical growth model and the value of multiplier was calculated above 1 in all cases with respect to efficiency of expenditures, delays in implementation and financing method of expenditure (Leeper et al., 2010: 1001). Ramey (2011b) calculated unproductive public expenditure elasticity $^{6}$ of total demand as 0.3 (multiplier coefficient about 1.5) in his study in which data of US defense expenditures were used. Some studies tried to estimate the effect of the value of expenditure multiplier on total demand in the long and short term. Accordingly, in the studies of Romer and Bernstein (2009) and Romer and Romer (2010) it was seen that governments' multiplier coefficient of current expenditures in the form of purchases of goods have taken higher values in the long term. However, in the estimations of Forni et al. (2009), Zubairy (2009) and Cogan et al. (2010) made through dynamic stochastic general estimation model and, Mountford and Uhlig (2009) made through VAR model it was found that the values of expenditure multiplier are higher in the short term.

Coenen et al. (2012) who estimated multiplier of government expenditures in USA by using nine different dynamic stochastic general equilibrium models found that multiplier of current expenditures of government relating to purchases of goods varies between 0.7 and 1 when there is no monetary regulation and it becomes more effective when money supply increases and varies between 1.2 and 2.2. In the model, it is assumed that decision-makers who can foresee the future will behave consistently with rational expectations hypothesis and the increase in expenditures will

\footnotetext{
${ }^{6}$ Expenditure elasticity of demand describes changes in consumption expenditures in response to a change in total expenditure level.
} 
Karaca, C.., \& Uğurlu, E. (2014). Measurement of efficiency of fiscal policies implemented for global crisis: Did Turkey have success in crisis management? International Journal of Human Sciences, 11(1), 920-947. doi: $\underline{10.14687 / \text { ijhs.v11i1.2867 }}$

be paid by them in a future period. So this assumption decreases the value of multipliers when rational expectations are included in the model. Additionally, multiplier coefficient of transfer expenditures was estimated in model and it was seen that multiplier of transfer expenditures made for low-income households varies between 1 and 1.5 when there is monetary regulation.

Auerbach and Gorodnichenko (2012a) calculated multiplier coefficient of current expenditures in normal and recession periods in the study in which used structuralVAR model for USA and found that coefficient is about zero in normal periods and reach 2.5 in recession periods ${ }^{7}$. Another study about the calculation of multiplier coefficient is in relation with stimulus package adopted by US government during crisis period. Congressional Budget Office measured the impact of stimulus package (The American Recovery and Reinvestment Act of 2009) which was adopted in 2009 on total demand and calculated multiplier coefficient of expenditure increase and tax cuts including in stimulus. Results of the estimations showed multiplier coefficient of current expenditures of government between 1 and 2.5, multiplier coefficient of transfer expenditures was found between 0.7 and 2.5, multiplier coefficient of payments to retirees was found between 0.3 and 1 . It the study in which tax cuts for low-income people, high-income people and corporations were calculated, multiplier coefficient of tax cuts for low-income people was found between 0.6 and 1.5, multiplier coefficient of tax cuts for high-income people was found between 0.2 and 0.6 , multiplier coefficient of tax advantages which provide cash flows to corporations is less than others and varies between 0 and 0.4. In a similar study carried out by Moody's on USA, it was found that as a result of food coupon distribution and unemployment pay to low-income people the value of multiplier on total demand are 1.73 and 1.64 respectively (IMF, 2008: 19).

Some studies found that development level of the countries have impact on the value of multiplier coefficient. In these studies which compare multiplier coefficient of government expenditures and tax cuts in developed countries such as US, Germany and Japan, it was found that the value of multiplier coefficients of these countries are higher than other compared countries (See Al-Eyd and Barrell, 2005; Henry et al., 2004; IMF, 2008: 20.).

\subsection{Analysis of Tax Policies}

In addition to expenditures, taxes are also an important tool fiscal policy used to overcome economic instability and to stimulate total demand. The analysis of impacts of tax policies on the market mainly concentrated on tax cuts. Basic characteristics of this process which is called as

\footnotetext{
${ }^{7}$ Studies which were carried out on other developed countries affirm that government expenditures multiplier is greater in recession periods than normal periods. For these studies, see Baum et al., (2012); Batini et al., (2012); IMF (2012).
} 
Karaca, C.., \& Uğurlu, E. (2014). Measurement of efficiency of fiscal policies implemented for global crisis: Did Turkey have success in crisis management? International Journal of Human Sciences, 11(1), 920-947. doi: $\underline{10.14687 / \text { ijhs.v11i1.2867 }}$

supply-side economic policy are explained through Haldun-Laffer effect. The argument, which is stated by Professor Arthur Laffer and which asserts that the decrease in tax rates would raise the economic growth and tax incomes, was also explained by philosopher Ibn Khaldun in $14^{\text {th }}$ century. Thus relationship between tax cuts and economic growth was defined as Haldun-Laffer effect in the literature. Ibn Khaldun explained the fact that tax cuts provide high tax incomes in his book 'The Muqaddimah' as follows; "It should be known that at the beginning of the dynasty, taxation yields large revenue from small assessments. At the end of the dynasty, taxation yields small revenue from large assessments." (Khaldun, 1981: 230).

In the $18^{\text {th }}$ century David Hume delivered a similar opinion and stated that high tax rates destroy industry and damage the economy. Another economist Michael Evans who made the econometric analysis of supply-side economics revealed the purposes of a balanced supply-side economic policy through a different approach. Accordingly, he stated that a cut in income tax and corporate tax decreases public expenditures and such a policy which contains legal and corporate liberalization enables high growth and low inflation (Aktan, 2000: 61-64).

Through tax cuts, it is targeted to increase disposable income in turn to increase consumption and investment expenditures. Elmendorf and Reifschneider (2002), who aimed to measure the effect of tax cuts on national income level, measured the effect of tax cuts in USA on national income through structural open economy model which was developed by Federal Reserve Board. Results of the estimation showed that income tax cuts increase real GDP; however this increase is lower than the amount of tax cuts. Estimations also showed that when 50 percent of temporary tax rebates which is 1 percent of GDP were spent, GDP would increase by $1 \%$ in the short term. Another result which was obtained from estimations showed that the effect of goods and services purchases at federal level on national income is higher than the effects of tax cut and investment allowances ${ }^{8}$. In another study oriented to US economy, Romer and Romer (2008) estimated that a tax increase which is $1 \%$ of GDP causes a 3\% decrease in output. The result of the study in which the effect of tax cuts in 9 EU member countries on national income was measured through QUEST model $^{9}$ by European Commission showed that a tax cut which is $1 \%$ of GDP increases

\footnotetext{
8 Results of studies in which the values of investment expenditures multiplier were calculated conduded that the values of investment expenditures multiplier are inconsistent as lower than 0 or greater than 4. Although it is theoretically known that investment expenditures stimulate private sector investments and these investments have a positive impact on input costs of private sector, satisfactory evidences could not be found about the fact that the value of investment expenditures multiplier is greater than the value of government expenditures multiplier. See IMF, 2008: 20.

${ }_{9}^{9}$ QUEST model was formed on the basis of fiscal sustainability in EU member countries. Accordingly, debt burden arising from fiscal incentives is attempted to be compensated through the increases in lump-sum taxes. So the value of multiplier is lower than the value in tax-free situation. Additionally, rational expectations were also induded in model and consumers may change their behaviors against the policy in a future period. See HM Treasury, 2003.
} 
Karaca, C.., \& Uğurlu, E. (2014). Measurement of efficiency of fiscal policies implemented for global crisis: Did Turkey have success in crisis management? International Journal of Human Sciences, 11(1), 920-947. doi: $\underline{10.14687 / \text { ijhs.v11i1.2867 }}$

national income by about 0.3 percent in first year. Another result of estimations indicates that the decrease in tax burden (supply-side) on producers have greater impact on national income in the long term.

There is a comprehensive literature about the long-term effects of taxation on growth. In the framework of neoclassical growth model, Solow (1956) advocates that taxation does not have an impact on growth in the long term. Most of the studies which examined the subject in the framework of internal growth model concluded that direct and indirect taxes have a negative impact on growth in the long term. However, there is a general acceptance that the effects of indirect taxes on growth are more limited than the effects of direct taxes (Durkaya and Ceylan, 2006: 82). In their study, King and Rebelo (1990) found that the effects of taxes are greater in outward-oriented economies and a change in tax rates has an important effect on growth. In the study, it was revealed that income taxes have a decreasing effect on per capita income in the long term. Zeng and Du (2003) examined the effects of taxes, which are collected on consumption, capital and labor, on long-term growth and the effects of type of tax income usages on growth process in the framework of Schumpeterian Growth Model. According to the findings, it was indicated that when all types of tax incomes are used for transfer expenditures all of three tax types affect growth negatively; however when taxes are used for public consumption goods income taxes affect growth negatively and consumption taxes does not have impact on growth. Finally, it was revealed that when tax incomes are used for current expenditure rather than transfer expenditures, the negative effect on the economic growth would decrease.

There are also studies which examine the effects of tax policies on national income in terms of Turkey. Durkaya and Ceylan (2006) used Engle-Granger cointegration test in order to examine long-term relationships; they used error correction model and granger causality test in order to examine short-term relationships. Findings showed that there is a bi-directional causality relationship between direct taxes and economic growth; and there is not any causality relationship between indirect taxes and economic growth. Temiz (2008) examined the relationship between total tax incomes, direct and indirect tax incomes, and real GDP with respect to the period of 1960 2006. In the study in which unit root, Johansen cointegration and error-correction models were used, it was found that tax incomes and GDP act together in the long term; and causality from growth rate of GDP to growth rate of total tax income was determined in the short-term. Mucuk and Alptekin (2008), who examined the period of 1975-2006 in Turkey, found a positive relationship between direct-indirect taxes and economic growth. 
Karaca, C.., \& Uğurlu, E. (2014). Measurement of efficiency of fiscal policies implemented for global crisis: Did Turkey have success in crisis management? International Journal of Human Sciences, 11(1), 920-947. doi: $\underline{10.14687 / \text { ijhs.v11i1.2867 }}$

In theory, it was foreseen that tax cuts without decreasing government expenditures during crisis periods will be paid off through borrowing in the future. However there are some arguments which discuss that when budget deficit arising from tax cuts is paid off through borrowing during crisis periods interest rates are not be affected due to the scarcity of loanable funds demand in these periods and the increase in disposable income which is provided by tax cuts creates an extending impact on total demand. Additionally, even if budget deficits arising from tax cuts are financed through borrowing, the increase in total demand provided by these cuts can compensate the costs of borrowing (Bugra, 1995:261). On the other hand, the financing of this deficit may not be always through borrowing. If the quantity of money in the economy is below the optimal money demand, governments can also finance the deficit through printing money.

\subsection{Analysis of the Effects of Fiscal Policies on Employment}

Studies in literature which examines the effects of fiscal incentives on employment found that stimulation of total demand through expenditure or tax cuts by the government increases production and investment, and so unemployment rates decrease in short and medium term (See Pappa, 2009; Ramey, 2012; Kato and Miyamoto, 2013). Monacelli et al. (2010) found in their study, which examines the effects of fiscal incentives implemented in USA during crisis period on labor force, that the increase in public expenditures which is $1 \%$ of GDP creates a 1.2 percent increase in production and a 0.6 percent decrease in unemployment rate. This result represents a higher rate than the result of the study which is carried out by Arthur Okun (1965) and found that each 1 percent increase in the real income of US decreases unemployment rate by 0.33 percent. The results showed also that each 1 percent increase in GDP produced by multiplier creates 1.3 million new job opportunities. He et al. (2009), who aimed to measure the effects of fiscal incentive measure taken by Chinese government to overcome the impacts of global crisis, found that the multiplier coefficient of stimulus packages which were adopted by Chinese government during the crisis is 0.84 in the short term and created 18-20 million additional employments in non-agricultural sectors. The study in which dynamic structural model was used found that the multiplier became 1.1 in the medium term with the effect of household consumption and corporate investments. Some studies which use stochastic general equilibrium model found that fiscal incentives decrease unemployment rate (See Yuan and Li, 2000; Monacelli et al., 2010; Campolmi et al., 2011; Brükner and Pappa, 2012).

Auerbach and Gorodnichenko (2012b), who examine the effect of increase in government expenditures on employment during economic stagnation and expansion periods, found that 1 
Karaca, C.., \& Uğurlu, E. (2014). Measurement of efficiency of fiscal policies implemented for global crisis: Did Turkey have success in crisis management? International Journal of Human Sciences, 11(1), 920-947. doi: $\underline{10.14687 / \text { ijhs.v11i1.2867 }}$

percent increase in government expenditures creates a 0.9 percent increase in private sector employment rate in the medium term, however this rate is close to zero in economic recovery periods in their study which examined OECD countries through panel data analysis. Some studies calculated how much expenditure can compensate each additional employment. Accordingly, Wilson (2012) stated that each additional employment needs 39.000 dollars government expenditure; Chodorow-Reich et al. (2012) stated that each additional employment needs 28.500 dollars government expenditure; Auerbach and Gorodnichenko (2012a) stated that each additional employment needs 23.000 dollars government expenditure.

\subsection{Borrowing Policies}

Budget should be balanced according to budget system which allows the collection of income and to make expenditures (Aksoy, 1993: 219). This principle adopted by classical economists and financers lost its validity after 1929 Great Depression and public expenditures which increased with acceptance of interventionist government idea began to be financed through borrowing. However there is still an uncertainty in literature about the direction of the effect of borrowing on the economy. Neoliberals argue that borrowings of public sector externalizes private sector investments due to the increasing costs of investment (crowding-out) and so government expenditures should be limited. An important point to which neoliberals do not pay attention is that at what extent will additional public expenditures be oriented to investment and whether these investments will affect private sector input costs positively. Neoliberal economists ruled out the fact that public investments will create a crowding-in effect which encourages private sector to invest by the way of decreasing input costs in the economy (Erdogdu, 2010:340). Additionally, the study of Friedman (1979) which analyses the result of financing of public deficits on the economy showed that externality varies with respect to the type and duration of financing and maturity structure of borrowing. The fact that public expenditures create a crowding out effect against private sector is possible when actual state of the economy is close to its potential. In stagnation periods when capacity utilization rate is at very low level in the economy, crowding out effect of public investments will not be a matter.

Demand shrinking, which arises from effective demand insufficiency and negative future expectations during crisis periods, provides governments the opportunities to use loanable funds and to stabilize the economy and to create a reasonable ground for the recovery from existing stagnation. This is because public-minded governments have better position than profit-oriented companies and they are more reliable in terms of credit risk in these periods. In the analysis on 
Karaca, C.., \& Uğurlu, E. (2014). Measurement of efficiency of fiscal policies implemented for global crisis: Did Turkey have success in crisis management? International Journal of Human Sciences, 11(1), 920-947. doi: $\underline{10.14687 / \text { ijhs.v11i1.2867 }}$

England which was carried out by Barrel et al. (2009) through National Institute international macro model, it was concluded that loans which are provided by the governments to individuals and firms who are below the borrowing constraint have a positive impact on output, investment and employment. Additionally, decisions of governments which may affect the costs of borrowing may show impact on effective demand. For instance, Eggertsson (2013:17) concluded in his model which is developed through dynamic general balance analysis that policies of governments which decrease the costs of borrowing create an expansionary effect on disposable income and so total demand is increased. Many studies tried to measure the effects of expansionary fiscal policies on output by establishing a connection with the level of borrowing interest rates. Cros s-sectional data analysis on US economy, which were carried out by Nakamura and Steinsson (2011) and Shoag (2010), concluded that when borrowing interest rate is zero multiplier coefficient of government expenditures is 1.5-2.2 higher than coefficient of higher-interest rate condition. The analysis, which is carried out by Eggertsson and Krugman (2012) through dynamic general balance model, indicated that when borrowing interest rates are determined at a level close to zero, this situation provides credit expansion, decreases the alternative cost of expenditure of savers and expands demand level, and showed that positive interest rate weakens the effect of fiscal policy. Some studies (Eggertsson, 2010; Christiano et al, 2011) found that fiscal incentives of countries decrease borrowing interest rates. Another study, in which IMF (2008: 27-28) examined the structures of past crises, 1997 South Korean Crisis could be overcome through successful measures of government and that long-term borrowing facilities, which were provided for SMEs by controlling decision processes of financial institutions, have an important role in this achievement.

\section{Method and Data Set}

In the study, three-variable structural VAR model which was developed by Blanchard and Perotti (1999) was used in order to measure the role of fiscal policies, which were implemented during crisis period, in the removal of impacts of crisis in the short term. This one-period-lagged model which allows concurrent interdependence between output, tax and expenditure in order to examine the effects of fiscal policies is shortly defined as follows;

$A_{0} Y_{t}=A_{1} Y_{t-1}+B \varepsilon_{t}$

In this equation, $Y_{t}=\left(T_{t}, E_{t}, X_{t}\right)$ is represented as the logarithmic vector of real tax incomes, real expenditure and real GDP; $\varepsilon_{t}$ is represented as mutually vertical vector of three common endogenous variables. 
Karaca, C.., \& Uğurlu, E. (2014). Measurement of efficiency of fiscal policies implemented for global crisis: Did Turkey have success in crisis management? International Journal of Human Sciences, 11(1), 920-947. doi: $\underline{10.14687 / \text { ijhs.v11i1.2867 }}$

As can be seen below, main assumption in the model of Blanchard and Perotti is that real GDP allows a concurrent effect on tax incomes but ignores effects on expenditure. Besides, despite the model shows that tax shocks affect expenditures within the year, it assumes that taxes are not concurrently dependent on expenditures. This assumption reflects for fiscal policies in Turkey that taxes are generally withheld from source and collected from consumption; expenditures are mostly applied with one-period lag; and institutional arrangements are limited in both automatic stabilizer and public sector size. The model of Blanchard and Perotti was adjusted for Turkey as follows;

$T_{t}=a_{0}^{13} X_{t}+a_{1}^{11} T_{t-1}+a_{1}^{12} E_{t-1}+a_{1}^{13} X_{t-1}+\varepsilon_{t}^{T}$

$E_{t}=a_{1}^{21} T_{t}+a_{1}^{22} T_{t-1}+a_{1}^{23} E_{t-1}+a_{1}^{24} X_{t-1}+b^{21} \varepsilon_{t}^{T}+\varepsilon_{t}^{E}$

$$
X_{t}=
$$

$a_{0}^{31} T_{t}+a_{0}^{32} E_{t}+a_{1}^{31} T_{t-1}+a_{1}^{32} E_{t-1}+a_{1}^{33} X_{t-1}+\varepsilon_{t}^{T}$

In the equation, $a_{0}^{i j}, a_{1}^{i j}$ and $b^{i j}$ represent $i^{\text {th }}$ and $j^{\text {th }}$ elements of $A_{0}, A_{1}$ and $B$ matrices. Thus, $a_{0}^{13}$ reflects the elasticity of tax incomes in the period versus GDP; $b^{21}$ reflects the effects of tax shocks on expenditures; and $a_{0}^{31}$ and $a_{0}^{32}$ allow taxes and expenditures to affect GDP concurrently. Here the attempt is to use independent data about the elasticity of tax incomes versus real GDP as in the model of Blanchard and Perotti in order to define the model (such as $a_{0}^{13}$ ). In this article, the coefficient which enables to estimate the model accurately was acknowledged as the studies of Giorno et al. (1995) and Kuttner and Posen (2002).

A sample period which contains the years between 2006 and 2013 was examined in the model in order to measure the efficiency of fiscal policies which were implemented in Turkey during the period of global crisis. Economic series of this period are series which have monthly frequency. It was focused on the period after 2007 in order to measure the efficiency of fiscal policies and following dummy variables were used for this period by considering the date implemented fiscal policies. The year of 2006 was acknowledged as the starting year due to lack of data on monthly basis. Additionally, a series which can represent monthly GDP series was needed. Since correlation coefficient between quarterly GDP and IPI series is about 0.99 , industrial production index (IPI) variable is used. Tax income series contains data of indirect and direct tax incomes. Public expenditures series comprises of data of current and investment expenditures. The reason of the fact that industrial production index is considered as a dependent variable is that this variables is an important macroeconomic indicator of real economy. Most of the studies, which used short-term 
Karaca, C.., \& Uğurlu, E. (2014). Measurement of efficiency of fiscal policies implemented for global crisis: Did Turkey have success in crisis management? International Journal of Human Sciences, 11(1), 920-947. doi: $\underline{10.14687 / \text { ijhs.v11i1.2867 }}$

and monthly data in order to measure economic performance, used industrial production index rather than $\mathrm{GDP}^{10}$.

Data which were used in the study were obtained from database of TCMB (CBT) and these data are Tax Revenues ${ }^{11}$ (TR), Government Expenditures ${ }^{12}$ (GE) and Industry Production Index (IPI) data respectively. Data were realized by using 2003=100 consumer price index (CPI). Firstly, data were eliminated from seasonality. Series which were seasonally adjusted were respectively named as TRSA, GESA and IPISA. Then logarithms of all data were taken and variables were named as LTRSA, LGESA and LIPISA. Prior requirement in VAR models is stationarity of series. Thus, Augmented Dickey-Fuller (ADF) and DF-GLS unit root tests were used in order to test whether series which are used in the study contain unit root. Although ADF is the widely used traditional unit root test De Jong et al. (1992) note that it has low power against the alternative hypothesis. Elliott, Rothenberg and Stock (ERS) (1996) develop a feasible point optimal test called DF-GLS (ERS) test which has generally higher power than the ADF unit root test.

Table 4: Unit Root Tests Results

\begin{tabular}{lccccc}
\hline & & \multicolumn{2}{c}{ Level } & \multicolumn{2}{c}{ First Difference } \\
\hline Variable & Model & ADF & DF-GLS & ADF & DF-GLS \\
\hline LTRSA & \multirow{2}{*}{ Constant } & $-1,5043(3)$ & $-0.2122(6)$ & $-10.0190(2)^{* * *}$ & $-0.5608(5)$ \\
LGESA & $-3.3553(1)^{*}$ & $0.07914(5)$ & $-8.0073(4)^{* * *}$ & $-0.4875(6)$ \\
LIPISA & & $-1.3246(1)$ & $0.1008(1)$ & $-18.4432(0)^{* * *}$ & $-0.7768(3)$ \\
\hline LTRSA & & $-3.0602(2)$ & $-2.8726(2)$ & $-9.9490(2)^{* * *}$ & $-1.4761(5)$ \\
LGESA & \multirow{2}{*}{ Constant+Trend } & $-10.0212(0)^{* * *}$ & $-4.8919(1)^{* * *}$ & $-8.0227(4)^{* * *}$ & $-1.2321(6)$ \\
LIPISA & & $-1.7368(1)$ & $-1.5832(1)$ & $-18.3054(0)^{* * *}$ & $-1.5811(3)$ \\
\hline
\end{tabular}

Values between parentheses show the value of lag in terms of SIC criterion. ${ }^{* * *}$,**,* respectively shows that $1 \%, 5 \%$ and $10 \% \mathrm{H}_{0}$ hypotheses are rejected and series is stationary.

According to the results of unit root tests, Table 4 shows that ADF test found government expenditures is stationary at level and other variables are stationary at first-difference. DF-GLS tests found that all variables are nonstationary even at first-difference except LGESA. According to the results of these two tests, it was decided that LTRSA and IPISA are stationary at first-difference and LGESA is stationary at level.

Before the analysis is carried out with SVAR model, unrestricted VAR model must be estimated. In this framework, lag length of estimated VAR model must be found. Six-lagged ${ }^{13}$ VAR model was

\footnotetext{
${ }^{10}$ For the studies, see Bilgin and Şahbaz (2009); Frankel and Saravelos (2010); Bekaert et al. (2010).

11 Tax incomes contain income and corporate tax, income tax withholding, value added tax and SCT which is collected on motor vehides and durable consumer goods.

12 Government expenditures consist of personnel expenditure, defense expenditures, health expenditures, treasury aids, transfers to households, agricultural subsidies, capital expenditure, capital transfers and interest payments.

13 Since the existence of autocorrelation cannot be rejected in lag which is determined in terms of SIC criterion, it was
} 
Karaca, C.., \& Uğurlu, E. (2014). Measurement of efficiency of fiscal policies implemented for global crisis: Did Turkey have success in crisis management? International Journal of Human Sciences, 11(1), 920-947. doi: $\underline{10.14687 / \text { ijhs.v11i1.2867 }}$

generated by taking first-differences of LTRSA and LIPISA variables and level value of LGESA variable (see Appendix 1 for the lag determination criterion). In this VAR model, existence of autocorrelation was tested through LM test and existence of heteroscedasticity was examined through White Test ${ }^{14}$; and the null hypothesis which indicates that there is no autocorrelation and the null hypothesis which indicates that there is no heteroscedasticity were rejected respectively. (See Appendix 2 and Appendix 3)

Sims (1980) acknowledged all variables in the model as endogenous in the model in which he examined dynamic interactions of all variables on one another by including lagged values of all variables. Sims (1986), Bernanke (1986), Shapiro and Watson (1988) developed 'Structural VAR' model and attempted to remove the negative conditions which arise from VAR model estimations. Authors focused on decomposition of distinguishing error-terms in system which are linear combination of exogenous shocks in the model. In SVAR model, restrictions which are applied the system are made on the basis of economic theory in contrast to VAR model (Güneş et al., 2013: 7).

A general SVAR model can be showed as follows;

$$
\begin{aligned}
& y_{1 t}=\gamma_{10}-b_{12} y_{2 t}+\gamma_{11} y_{1 t-1}+\gamma_{12} y_{2 t-1}+\varepsilon_{1 t} \\
& y_{2 t}=\gamma_{20}-b_{21} y_{1 t}+\gamma_{21} y_{1 t-1}+\gamma_{22} y_{2 t-1}+\varepsilon_{2 t}
\end{aligned}
$$

where

$$
\left(\begin{array}{l}
\varepsilon_{1 t} \\
\varepsilon_{2 t}
\end{array}\right) \sim \text { i.i.d. }\left(\left(\begin{array}{l}
0 \\
0
\end{array}\right),\left(\begin{array}{ll}
\sigma_{1}^{2} & 0 \\
0 & \sigma_{2}^{2}
\end{array}\right)\right)
$$

The sample consists of observations from $t=1, \ldots, T$ with a fixed initial value $y 0=(y 10, y 20)$. The exogenous error terms $\varepsilon_{1 t}$ and $\varepsilon_{2 t}$ are independent and are interpreted as structural innovations.

\subsection{Long-term Restricted VAR Model}

In this study, long-term multiplier matrix was estimated through structural VAR model by equalizing the elasticity of IPI variable, which shows revenue variable, to 1.25 as used in the model of Blanchard and Perotti. Güneş et al. (2013) stated that coefficient of multiplier matrix could not be interpreted only signs of them interested 
Karaca, C.., \& Uğurlu, E. (2014). Measurement of efficiency of fiscal policies implemented for global crisis: Did Turkey have success in crisis management? International Journal of Human Sciences, 11(1), 920-947. doi: $\underline{10.14687 / \text { ijhs.v11i1.2867 }}$

Table 5: Relationship between Tax Revenues, Government Expenditures and Revenue (IPI)

\begin{tabular}{lccc}
\hline & \multicolumn{3}{c}{ Equation } \\
\cline { 2 - 4 } IndependentVariables & Taxes & Expenditure & IPI \\
\hline LTRSA & - & $0.0208^{* * *}$ & $0.0062^{* * *}$ \\
LGE & - & - & $0.3425^{* *}$ \\
LIPI & 1.25 & & \\
\hline
\end{tabular}

Source: calculations are coefficients which were calculated through SVAR model.

Note: ${ }^{* *}$ and ${ }^{* *}$ represent the statistical significance at 0,01 and 0,05 at significance level.

As can be seen in Table 5, all variables are statistically significant. Tax revenues have significant impact on government expenditures and revenue at $1 \%$ positive significance level. The impact of government expenditures on revenue is positive at $5 \%$ significance level. After the model was estimated, responses to a shock in expenditures were examined through impulse response functions by using from error-terms of the model. Impulse Response functions graph is seen as follows;

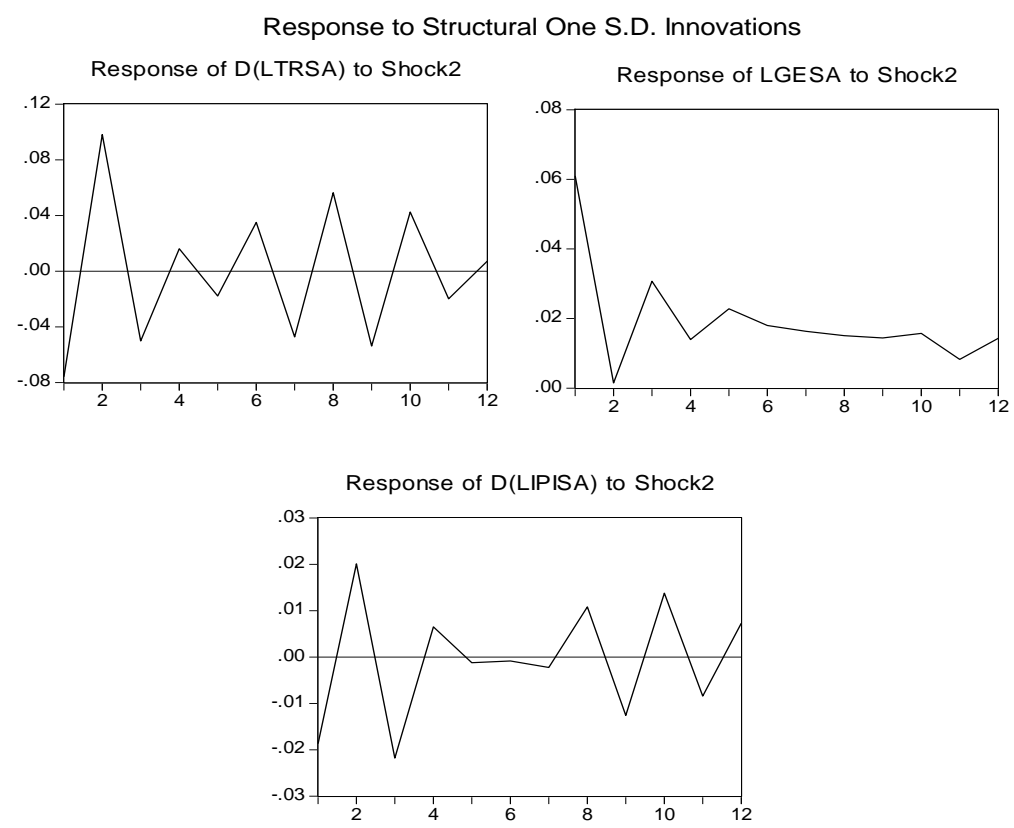

Figure 1. Impact of a Shock in Expenditures in Long-term Structural VAR Model

A shock in expenditures increases taxes in first period, and then it causes a decrease in taxes after second period. After second period, shocks maintain in the form of increase/decrease. The effect of a shock in expenditures on expenditures has generally decreasing effect. It only created an increase when passing from second period to third period, and after that period it caused the decrease. Finally, the effect of a shock in expenditures on IPI variable firstly shows an increasing effect and then decreasing effect. Effects of the expenditures shocks do not disappear on those three variables at the end of year. 
Karaca, C.., \& Uğurlu, E. (2014). Measurement of efficiency of fiscal policies implemented for global crisis: Did Turkey have success in crisis management? International Journal of Human Sciences, 11(1), 920-947. doi: $\underline{10.14687 / \text { ijhs.v11i1.2867 }}$

In addition to impulse response functions, variance decomposition analysis can be carried out in structural VAR models as in VAR models. Variance decomposition determines which variable is most effective on a macroeconomic value.

Table 6: Variance Decomposition Results of Long Run Structural VAR Model

\begin{tabular}{|c|c|c|c|c|c|c|c|c|c|}
\hline \multicolumn{10}{|c|}{ Variance Decomposition } \\
\hline Variable & \multicolumn{3}{|c|}{ D(LTRSA) } & \multicolumn{3}{|c|}{ LGESA } & \multicolumn{3}{|c|}{ LIPISA } \\
\hline Period & Shodk1 & Shodk2 & Shock3 & Shodk1 & Shodk2 & Shodk3 & Shodk1 & Shodk2 & Shodk3 \\
\hline 1 & 99.3778 & 0.4807 & 0.1413 & 91.9243 & 2.0518 & 6.0238 & 99.9807 & 0.001 & 0.0182 \\
\hline 2 & 99.0733 & 0.6979 & 0.2286 & 96.2572 & 1.0365 & 2.7061 & 99.9724 & 0.0007 & 0.0267 \\
\hline 3 & 99.1931 & 0.5808 & 0.226 & 96.1179 & 0.9577 & 2.9242 & 99.9638 & 0.0006 & 0.0355 \\
\hline 4 & 99.4885 & 0.3642 & 0.1472 & 95.9822 & 1.0596 & 2.9581 & 99.9629 & 0.0006 & 0.0364 \\
\hline 5 & 99.5298 & 0.3306 & 0.1394 & 98.1971 & 0.4489 & 1.3539 & 99.9609 & 0.0027 & 0.0362 \\
\hline 6 & 99.4875 & 0.3442 & 0.1682 & 99.0348 & 0.2412 & 0.7239 & 99.9597 & 0.004 & 0.0362 \\
\hline 7 & 99.4882 & 0.3197 & 0.192 & 98.9429 & 0.3051 & 0.7518 & 99.9585 & 0.0052 & 0.0362 \\
\hline 8 & 99.6024 & 0.2279 & 0.1696 & 98.9832 & 0.2979 & 0.7188 & 99.9556 & 0.0059 & 0.0384 \\
\hline 9 & 99.6679 & 0.1788 & 0.1532 & 99.1641 & 0.2486 & 0.5872 & 99.952 & 0.0062 & 0.0417 \\
\hline 10 & 99.6902 & 0.1608 & 0.1488 & 99.2939 & 0.2054 & 0.5006 & 99.9473 & 0.0063 & 0.0463 \\
\hline 11 & 99.6986 & 0.1731 & 0.1281 & 99.2899 & 0.3667 & 0.3432 & 99.9457 & 0.0444 & 0.0098 \\
\hline 12 & 99.6985 & 0.1732 & 0.1282 & 99.2744 & 0.3767 & 0.3487 & 99.9446 & 0.0453 & 0.0100 \\
\hline
\end{tabular}

In the results of variance decomposition, when it is focused on expenditure variable, these shocks explain tax revenues variable $48 \%$ in first period; $70 \%$ in second period; and explanation rate decrease and becomes $1 \%$ in $10^{\text {th }}$ period. Self-explanation rate of shock in expenditure variable is also very low. It can explain only about $1 \%$ of its own movements along 10 periods. However, the main shock affecting expenditure variable is the shock in tax revenues variable which begins with $91 \%$ in first period. Finally, the effect of expenditure variable on revenue variable is very low. When the results of the variance decomposition are totally examined it is seen that the most effective shock is tax revenues.

\subsection{Short-term Restricted VAR Model}

Structural VAR model was estimated by using short-term restrictions in Model 2. According to the results of LR test, null hypothesis cannot be rejected thus restrictions are valid (See Appendix 4). Thus, the validity of restriction was accepted. Effects of the shocks in expenditure variable in the short term on other variables are seen in Figure 2. 
Karaca, C.., \& Uğurlu, E. (2014). Measurement of efficiency of fiscal policies implemented for global crisis: Did Turkey have success in crisis management? International Journal of Human Sciences, 11(1), 920-947. doi: $\underline{10.14687 / \text { ijhs.v11i1.2867 }}$

Response to Structural One S.D. Innovations \pm 2 S.E.
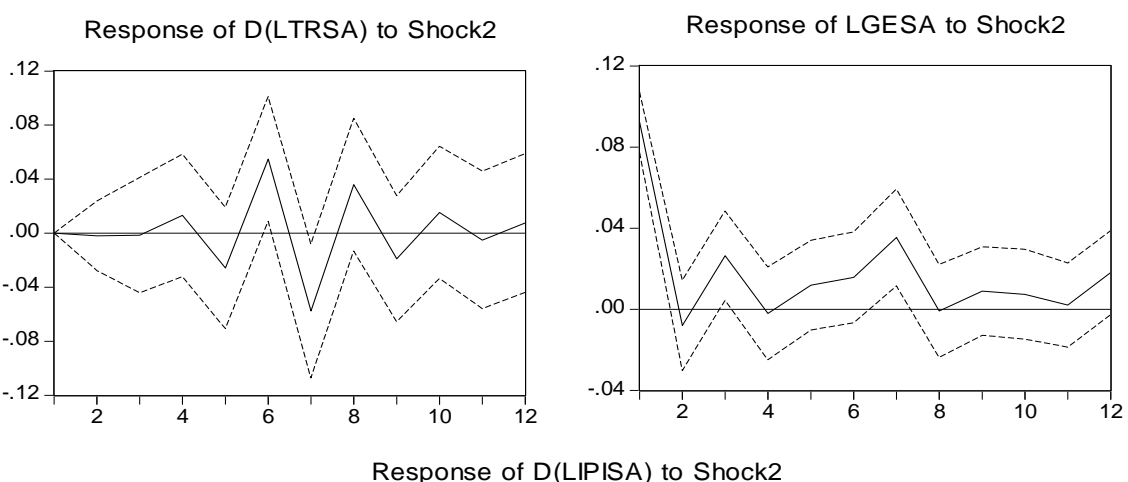

Response of D(LIPISA) to Shock2

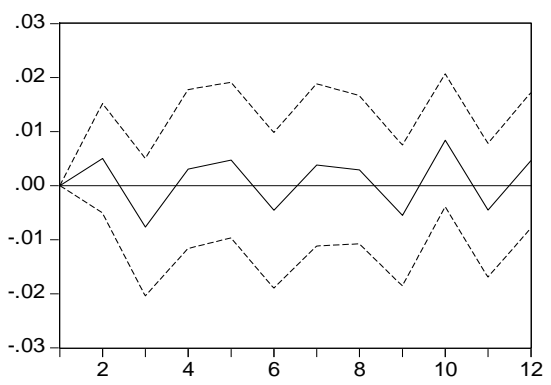

Figure 2.Impact of a Shock in Expenditures in Short-term Structural VAR Model

As can be seen in Figure 2, impulse-response graphs are in $\% 5$ confidence interval bands. A shock in expenditures decreases tax revenues in first three periods; then effects maintain in the form of increase/decrease. It is seen that effect of a shock in expenditures on itself does not show a general tendency and there is not a negative effect but positive effects except in two periods. The effect of a shock in expenditures on IPI variable firstly shows an increasing effect and then decreasing effect.

Table 7: Variance Decomposition Results of Short Run Structural VAR Model

\begin{tabular}{cccccccccc}
\hline \multicolumn{7}{c}{ Variance Decomposition } \\
\hline Variable & \multicolumn{3}{c}{ D(LTRSA) } & \multicolumn{3}{c}{ LGESA } & & LIPISA \\
\hline Period & Shock1 & Shock2 & Shock3 & Shock1 & Shock2 & Shock3 & Shock1 & Shock2 & Shock3 \\
\hline 1 & 100.0000 & 0.0000 & 0.0000 & 1.0909 & 98.9091 & 0.0000 & 0.0000 & 0.0000 & 100.0000 \\
2 & 99.3161 & 0.0132 & 0.6707 & 2.7699 & 96.8607 & 0.3694 & 0.9611 & 1.5940 & 97.4449 \\
3 & 94.4800 & 0.0189 & 5.5011 & 6.0402 & 93.4469 & 0.5130 & 2.4637 & 3.5287 & 94.0076 \\
4 & 89.7826 & 0.5223 & 9.6951 & 8.8295 & 90.2981 & 0.8724 & 2.6994 & 3.8309 & 93.4698 \\
5 & 86.8212 & 2.3404 & 10.8384 & 9.2579 & 86.3886 & 4.3535 & 3.2725 & 5.1602 & 91.5672 \\
6 & 79.9792 & 9.8918 & 10.1290 & 12.0658 & 82.6288 & 5.3054 & 3.7933 & 5.7310 & 90.4757 \\
7 & 72.1523 & 16.6093 & 11.2384 & 11.4571 & 83.6252 & 4.9177 & 4.1479 & 6.4883 & 89.3638 \\
8 & 65.3687 & 17.6449 & 16.9864 & 12.6947 & 81.4055 & 5.8998 & 4.2351 & 8.3889 & 87.3760 \\
9 & 61.0502 & 16.8671 & 22.0828 & 14.6250 & 79.2019 & 6.1731 & 4.8288 & 9.9876 & 85.1836 \\
10 & 59.0074 & 16.5212 & 24.4714 & 14.4152 & 77.4292 & 8.1557 & 6.3250 & 11.4414 & 82.2336 \\
11 & 58.4000 & 16.3599 & 25.2401 & 14.7618 & 77.0429 & 8.1954 & 6.7025 & 11.7817 & 81.5158 \\
12 & 58.3156 & 16.4394 & 25.2450 & 14.5658 & 77.4328 & 8.0014 & 7.1096 & 11.7763 & 81.1141 \\
\hline
\end{tabular}

Result of variance decomposition which was obtained through short-term structural VAR model shows that highest effect of a shock in expenditures is on expenditures. The interpretation of the 
Karaca, C.., \& Uğurlu, E. (2014). Measurement of efficiency of fiscal policies implemented for global crisis: Did Turkey have success in crisis management? International Journal of Human Sciences, 11(1), 920-947. doi: $\underline{10.14687 / \text { ijhs.v11i1.2867 }}$

analysis is the percentage of the variance of the error made in forecasting a variable due to a specific shock of error term in considered expenditure equation. Expenditure has highest explanatory ratio on its forecast values that is $\% 98$ in first period and $\% 77$ end of the year. Although tax revenues have a $\% 1$ explanatory ratio on expenditure it was reached nearly $\% 15$ end of the year.

\section{Result and Assessment}

In the study, the efficiency of fiscal policies which were implemented in Turkey during global crisis was examined. In accordance with this purpose, industry production index, public expenditure and tax revenue variables were analyzed on behalf of economic growth through structural VAR model for the period of 2006M1-2012M12. In the analysis, the power of explanation of growth rate in Turkey by public expenditures shocks and tax revenue shocks which were implemented by the government was examined. According to the results of analysis, a shock in expenditures firstly increases growth then decreases it. This effect does not disappear until the end of the year. Additionally, $12 \%$ of changes in growth in short term are explained through public expenditures. Continuance of this effect until the end of the period is consistent with the foresight that the effect of public expenditures on national income increases on the basis of the value of multiplier coefficient.

Results of the estimation are consistent with the theory; however produced indicators cannot sufficiently represent the whole economy due to the lack of data as the most of the existing studies which were carried out for Turkish economy. The main problems of this issue are as follows; existing data mostly have general series relating to government expenditures and revenues, these series do not contain adequate time series and there aren't data about specific incentives which were implemented by the government in export, tax cuts, unemployment etc. Accordingly, an estimation of fiscal policies which were implemented in Turkey during global crisis was made by using industry production, general public expenditures and tax revenues variables. Most important point of the estimation results is that government expenditures have a positive effect on growth. So some general statements about public expenditures of countries during crisis periods can be made.

One of the important arguments of classical and neoliberal economists is the fact that the increase in public expenditures causes budget deficit and if this deficit is compensated with borrowings and tax incomes, crowding out effect arises in the economy by increasing the costs of investment of private sector. However, estimation results, which claim that public expenditures affect growth positively, show that this prediction is not valid in all conditions. The fact that public expenditures during crisis periods affect the costs of investment of private sector is not possible when the 
Karaca, C.., \& Uğurlu, E. (2014). Measurement of efficiency of fiscal policies implemented for global crisis: Did Turkey have success in crisis management? International Journal of Human Sciences, 11(1), 920-947. doi: $\underline{10.14687 / \text { ijhs.v11i1.2867 }}$

economy is below the potential growth trend. In crisis periods, capacity utilization rate of firms decrease so they cannot make investment and they cannot sell off their existing stocks because of lack of total demand. In such a condition, increasing of the consumption through government expenditures cannot generate crowding-out effect and contrary it provides firms and opportunity to sell off their stocks. Regardless of the type of expenditures (real expenditure or transfer expenditure), in these two conditions these expenditures deliver the economy which is below the growth trend to full employment balance level by showing positive impact on disposable incomes of individuals on the basis of the greatness of multiplier coefficient in the economy. Furthermore, since firms and individuals have negative future expectations during crisis periods, demand to loanable funds in the economy for consumption and investment decreases. In such a condition in which incomes of financial sector decrease, governments' borrowing from banks and transferring of these borrowing to economy by using in the economy can be explained only by a crowding-in effect.

As can be understood from these explanations, unprecedented government policies which were implemented by the government in Turkey are successful fiscal policies which enable to overcome the crisis. While law no 5763 which was adopted in 2008 for employment incentive and council of ministers decision no 15199 'Government Support in Investment' which was adopted in 2009 generate burden on government budget, it can be said that these expenditures are successful fiscal policy measures to overcome the crisis. Main reason of unemployment problem which is generated in stagnation periods is insufficient total demand. So government should take measures to stimulate demand and decrease labor cost in real sector to prevent severances until the period in which recovery begins. Thus, the expenditures which are made in such a condition attempting to lower labor costs of employers will probably be lower than the cost which arises from stagnation in contrary condition, because each unemployed individual means more shrinking of total demand as revealed in Keynesian economic theory. New demand shrinking will cause new severances and new severances will cause new demand shrinking.

According to the results of the estimation, coefficient of net tax incomes was found positive and statistically significant. Sign and coefficient of this variable is consistent with the literature. In other words, increases in net tax revenues n given period raise national income. Additionally, according to the analysis results, 7\% of short-term changes in growth are explained through tax incomes. Especially, the stimulus package which was implemented by the government in the first quarter of 2009 forecast temporary cuts in special consumption tax and value-added tax; and this stimulus provided important increases in capacity utilization rates in all sectors which were in the scope of 
Karaca, C.., \& Uğurlu, E. (2014). Measurement of efficiency of fiscal policies implemented for global crisis: Did Turkey have success in crisis management? International Journal of Human Sciences, 11(1), 920-947. doi: $\underline{10.14687 / \text { ijhs.v11i1.2867 }}$

the cuts. This package provided the stimulation of demand in uncertainty and stagnation period, it generated an increase in production, national income and tax income.

\section{REFERENCES}

Aksoy, S. (1993). Kamu Bütçesi, Filiz Kitabevi, İstanbul.

Aktan, C. C. (2000). Politik İktisat, İzmir: Anadolu Matbaasi.

Al-Eyd, A. J. and R. Barrell (2005). Estimating Tax and Benefit Multipliers in Europe. Economic Modeling. Vol. 22. ss. 759-76. doi: 10.1016/j.econmod.2005.05.005

View Article: DOI: http://dx.doi.org/10.1016/j.econmod.2005.05.005

Auerbach, A. J. and Y. Gorodnichenko (2012a). Measuring the Output Responses to Fiscal Policy. American Economic Review: Economic Policy. 4. ss. 1-27.

Auerbach, A. J. and Y. Gorodnichenko (2012b). Fiscal Multipliers in Recession and Expansion. in Fiscal Policy after the Financial Crisis. A. Alesina and F. Giavazzi (Ed.) Chicago: University of Chicago Press.

Barrell, R., T. Fic and İ. Liadze (2009). Fiscal Policy Effectiveness İn The Banking Crisis. National Institute Economic Review, 207: 43. doi: 10.1177/0027950109103678

View Article: DOI: http://dx.doi.org/10.1177/0027950109103678

Batini, N., G. Callegari and G. Melina (2012). Successful Austerity in the United States, Europe and Japan. IMF Working Paper No. 12/190 (Washington: International Monetary Fund).

Baum, A., M. Poplawski-Ribeiro and A. Weber (2012). Fiscal Multipliers and the State of the Economy. IMF Working Paper No. 12/286 (Washington: International Monetary Fund).

Bekaert, G., M. Hoerova and M. L. Duca (2010). Risk, Uncertainty And Monetary Policy. NBER Working Paper Series, Working Paper 16397, National Bureau of Economic Research, Cambridge.

Bernanke, Ben S. (1986). Alternative explanations of money-income correlation. CarnegieRochester Conference Series on Public Policy, 25, 49-100.

Bilgin, C. and A. Sahbaz (2009). Türkiye'de Büyüme ve İhracat Arasindaki Nedensellik İliskileri. Gaziantep Üniversitesi Sosyal Bilimler Dergisi, 8(1): 177-198.

Blanchard, O., and R. Perotti (1999). "An Empirical Characterization of the Dynamic Effects of Changes in Government Spending and Taxes on Output," Working Paper 7269, National Bureau of Economic Research.

Brückner, M. and E. Pappa. (2012). Fiscal Expansions, Unemployment, and Labor Participation. İnternational Economic Review. 53. ss. 1205-1228. doi: 10.1111/j.1468-2354.2012.00717.x

View Article: DOI: http://dx.doi.org/10.1111/j.1468-2354.2012.00717.x

Campolmi, A., E. Faia and R. Winkler (2011). Fiscal Calculus and the Labor Market. The B.E. Journal of Macroeconomics. Volume 11, İssue 1.

Central Bank (2012). General Statistic, TCMB Dynamic And İnteractive Data Dissemination System.

Chodorow-Reich, G., L. Feiveson, Z. Liscow and W. Woolston (2012). Does State Fiscal Relief During Recessions İncrease Employment? Evidence from the American Recovery and 
Karaca, C.., \& Uğurlu, E. (2014). Measurement of efficiency of fiscal policies implemented for global crisis: Did Turkey have success in crisis management? International Journal of Human Sciences, 11(1), 920-947. doi: $10.14687 /$ ijhs.v11i1.2867

Reinvestment Act. American Economic Journal: Economic Policy. pp. 118-145(28). doi: 10.1257/pol.4.3.118

View Article: DOI: http://dx.doi.org/10.1257/pol.4.3.118

Christiano, L., M. Eichenbaum, and S. Rebelo (2011). When is the Government Spending Multiplier Large?, Journal of Political Economy, 119, 78-121.

Coenen, Günter, Christopher J. Erceg, Charles Freedman, Davide Furceri, Michael Kumhof, René Lalonde, Douglas Laxton, Jesper Lindé, Annabelle Mourougane, Dirk Muir, Susana Mursula, Carlos de Resende, John Roberts, Werner Roeger, Stephen Snudden, Mathias Trabandt, and Jan in't Veld (2012). Effects of Fiscal Stimulus in Structural Models. American Economic Journal: Macroeconomics, 4, 22-68. doi: 10.1257/mac.4.1.22

View Article: DOI: http://dx.doi.org/10.1257/mac.4.1.22

Cogan, John F., T. Cwik, J. B. Taylor, V. Wieland (2010). New Keynesian versus old Keynesian government spending multipliers. Journal of Economic Dynamics and Control. Volume 34. İssue 3. March. ss. 281-295.doi: 10.1016/j.jedc.2010.01.010

View Article: DOI: http://dx.doi.org/10.1016/j.jedc.2010.01.010

Congressional Budget Office (2010). Estimated Impact of the American Recovery and Reinvestment Act on Employment and Economic Output from October 2009 through December 2009. February.

DeJong, D. N., J. C. Nankervis, N. E. Savin and C. H. Whiteman (1992). The power problems of unit root tests in time series with autoregressive errors. J. Econometrics 53, 323-43. doi: 10.1016/0304-4076(92)90090-E

View Article: DOI: http://dx.doi.org/10.1016/0304-4076(92)90090-E

DPT (2009). 2009 Yili Katilim Öncesi Ekonomik Program. Devlet Planlama Teskilati. Ankara.

Durkaya, M. and S. Ceylan (2006). "Vergi Gelirleri ve Ekonomik Büyüme”, Maliye Dergisi, Sayi 150 http://dergiler.sgb.gov.tr/calismalar/maliye dergisi/yayinlar/md/150/mdurkaya sceylan.p df

Eggertsson, G. B. (2010). What Fiscal Policy İs Effective at Zero İnterest Rates?, in NBER Macroeconomics Annual 2010, ed. by D. Acemoglu, and M. Woodford, Chicago İ. University of Chicago Press.

Eggertsson, G. B. (2013). Fiscal Policy, Public Debt and the World Crisis. German Economic Review 1(1): 1-18.

Eggertsson, G. B. and P. Krugman (2012). "Debt, Deleveraging, and the Liquidity Trap: A FisherMinsky-Koo approach", Quarterly Journal of Economics, 127(3): 1469-1513. doi: 10.1093/qje/qjs023

View Article: DOI: http://dx.doi.org/10.1093/qje/qjs023

Elliott, G., Rothenberg, T. J., and J. H. Stock (1996). Efficient tests for an autoregressive unit root. Econometrica, 64, 813-836

Elmendorf, D. W. and D. L. Reifschneider (2002). Short-Run Effects of Fiscal Policy with Forward-Looking Financial Markets. National Tax Journal. Vol. LV. No. 3. September.

Erdogdu, M. M. (2010). Neo-liberal İktisatta Sonun Baslangici ve Keynezyen İktisadin Reenkarnasyonu. H. Kapucu, M. Aydin, İ. Siriner, F. Morady ve Ü. Çetin (ed.). Politik İktisat ve Adam Smith. Yön Yayinlari. ss. 329 - 358. 
Karaca, C.., \& Uğurlu, E. (2014). Measurement of efficiency of fiscal policies implemented for global crisis: Did Turkey have success in crisis management? International Journal of Human Sciences, 11(1), 920-947. doi: $\underline{10.14687 / \text { ijhs.v11i1.2867 }}$

European Commission (2011). Turkey Progress Report, SEC (2011) 1201, Brüksel. http://www.abgs.gov.tr/files/AB İliskileri/AdaylikSureci/IllerlemeRaporlari/2011 ilerlem e raporu tr.pdf

Forni, L., L. Monteforte, L. Sessa (2009). The general equilibrium effects of fiscal policy: estimates for the Euro area. Journal of Public Economics. 93 (3-4). ss. 559-585.

Frankel, J. A. and Saravelos, G. (2010). Are Leading İndicators of Financial Crises Useful for Assessing Country Vulnerability? Evidence from the 2008-09 Global Crisis, NBER Working Paper 16047.

Frenkel, R. and M. Rapetti (2009). "A developing country view of the current global crisis: what should not be forgotten and what should be done", Cambridge Journal of Economics, 33, ss. 685-702. doi: $10.1093 / \mathrm{cje} /$ bep029

View Article: DOI: http://dx.doi.org/10.1093/cje/bep029

Friedman, Benjamin M. (1979). Crowding Out Or Crowding İn? The Economic Consequences of Financing Government Deficits. NBER Working Paper No. 284.

Giorno, C., P. Richardson, D. Roseveare ve P. van den Noord (1995). Estimating Potential Output, Output Gaps, and Structural Budget Balances. Working Paper 152, Organisation for Economic Cooperation and Development.

Günes, S., P. Gurel and B. Cambazoglu (2013). "Dis Ticaret Hadleri, Dünya Petrol Fiyatlari ve Döviz Kuru İliskisi, Yapisal Var Analizi: Türkiye Örnegi”,İnt. Journal of Management Economics and Business, Vol. 9, No. 20.

He, D., Z. Zhang and W. Zhang (2009). How Large Will Be the Effect of China's Fiscal Stimulus Package on Output and Employment?. Pacific Economic Review. Volume 14. İssue 5. ss. 730-744. http://onlinelibrary.wiley.com/doi/10.1111/j.1468-0106.2009.00480.x/full

Henry, J., P. Hernandez de Cos and S. Momigliano (2004). The Short-Term Impact of Government Budgets on Prices. Evidence from Macroeconometric Models. European Central Bank Working Paper Series. No. 396.

HM Treasury (2003). Fiscal Stabilization and EMU. Discussion Paper.

International Monetary Fund (2008). Fiscal Policy for the Crisis (by A. Spilimbergo, S. Symansky, O. Blanchard, and C. Cottarelli). IMF Staff Position Note, SPN/08/01

International Monetary Fund (2012). World Economic Outlook: Coping with High Debt and Sluggish Growth (Washington: International Monetary Fund, October).

Kato, R. R. and H. Miyamoto (2013). Fiscal Stimulus in an Endogenous Job Separation Model. International University of Japan Research Institute, Economics and Management Series EMS-2013-02, http://www.iuj.ac.jp/research/workingpapers/EMS 2013 02.pdf

Khaldun, İbn. (1981). The Muqaddimah - An Introduction to the History - 5th Ed. N. J. Daood (Ed) ve P. Rdsenthal (Trans.). Princeton University Press.

King R.G. and S. Rebelo (1990). "Pulic Policy and Economic Growth: Devoloping Neoclassical Implications", Journal of Political Economy 98:5, ss126-150.

Krugman, P. and R. Wells (2006). The Health Care Crisis and What to Do about İ. New York Review of Books. March 23.

Kuttner, K. N. and A. S. Posen (2002). Fiscal Policy Effectiveness in Japan. Journal of the Japanese and İnternational Economies 16, 536-558. doi: 10.1006/jjie.2002.0512 
Karaca, C.., \& Uğurlu, E. (2014). Measurement of efficiency of fiscal policies implemented for global crisis: Did Turkey have success in crisis management? International Journal of Human Sciences, 11(1), 920-947. doi: $10.14687 /$ ijhs.v11i1.2867

View Article: DOI: http://dx.doi.org/10.1006/jjie.2002.0512

Leeper, Eric M., Todd B.Walker and Shu-Chun S.Yang (2010). Government investment and fiscal stimulus. Journal of Monetary Economics. 57. ss. 1000-1012. doi: 10.1016/j.jmoneco.2010.09.002

View Article: DOI: http://dx.doi.org/10.1016/j.jmoneco.2010.09.002

Monacelli, T., R. Perotti and A. Trigari (2010). Unemployment fiscal multipliers. Journal of Monetary Economics. Volume 57. İssue 5. July. ss. 531-553. http://www.sciencedirect.com/science/article/pii/S0304393210000553

Mountford, A. and H. Uhlig (2009). What are the effects of fiscal policy shocks?. Journal of Applied Econometrics. 24 (6). ss. 960-992. doi: 10.1002/jae.1079

View Article: DOI: http://dx.doi.org/10.1002/jae.1079

Mucuk, M. and V. Alptekin (2008). Türkiye'de Vergi ve Ekonomik Büyüme İliskisi: VAR Analizi (1975 - 2006). Maliye Dergisi, Sayi: 155.

Nakamura, E. and J. Steinsson (2011). Fiscal Stimulus in a Monetary Union: Evidence from U.S. Regions, NBER Working Paper No. w17391.

Official Journal. 5763 Sayili İs Kanunu ve Bazi Kanunla rda Degisiklik Yapilmasi Hakkinda Kanun. 26 Mayis 2008 tarihli Resmi Gazete.

Official Journal. 5811 sayili Bazi Varliklarin Milli Ekonomiye Kazandirilmasi Hakkinda Kanun. 22 Kasim 2008 Tarihli ve 27062 Sayili Resmî Gazete.

Official Journal. 5838 sayili Bazi Kanunlarda Degisiklik Yapilmasi Hakkinda Kanun. 28.02.2009 tarihli 27155 sayili Resmi Gazete

Official Journal. 5904 sayili Gelir Vergisi Kanunu ve Bazi Kanunlarda Degisiklik Yapilmasi Hakkinda Kanun. 3 Temmuz 2009 Tarihli ve 27277 Sayili Resmî Gazete

Official Journal. Bazi Mallara Uygulanacak Katma Deger Vergisi ile Özel Tüketim Vergisi Oranlarinin Belirlenmesine Dair Karar. 2009/14802 sayili Bakanlar Kurulu Karari, 16 Mart 2009 tarihli ve 27171 Sayili Resmî Gazete

Official Journal. Kaynak Kullanimini Destekleme Fonu Kesintileri Hakkinda Kararin Yürürlülüge Konulmasi Hakkinda Karar. 2009/14803 sayili Bakanlar Kurulu Karari. 16 Mart 2009 tarihli ve 27171 Sayili Resmî Gazete

Official Journal. Kisa Çalisma Süresinin Alti Ay Uzatilmasi Hakkinda Bakanlar Kurulu Karari. 2 Temmuz 2009 Tarihli ve 27276 Sayili Resmî Gazete. 009/15129

Official Journal. Yatirimlarda Devlet Yardimlari Hakkinda Karar. 2009/15199. 16 Temmuz 2009 Tarihli ve 27290 Sayili Resmî Gazete

Okun, Arthur M. (1965). The Gap between Actual and Potential Output. E. S. Phelps (ed.). Problems of the Modern Economy içinde. New York: Norton, ss. 287-96.

Onder, İ. (2012). Maliye Politikasi: Kavramlar, Etkinligi ve Sinirlari, Maliye Politikasi İ içinde (Ed. Ataç, B.). 1. Baski, Eskisehir: Anadolu Üniversitesi Yayini No: 2560, Eskisehir.

Pappa, E. (2009). The effects of fiscal shocks on employment and the real wage. International Economic Review. 50 (1) ss. 217-244. http://onlinelibrary.wiley.com/doi/10.1111/j.14682354.2008.00528.x/full 
Karaca, C.., \& Uğurlu, E. (2014). Measurement of efficiency of fiscal policies implemented for global crisis: Did Turkey have success in crisis management? International Journal of Human Sciences, 11(1), 920-947. doi: $\underline{10.14687 / \text { ijhs.v11i1.2867 }}$

Ramey, V. A. (2011a). Can Government Purchases Stimulate the Economy?. Journal of Economic Literature. 49. ss. 673-685. http://relooney.fatcow.com/0 New 11268.pdf

Ramey, V. A. (2011b). İdentifying Government Spending Shocks: İt's all in the Timing, The Quarterly Journal of Economics, Oxford University Press, vol. 126(1). 1-50.

Ramey, V. A. (2012). Government Spending and Private Activity. National Bureau of Economic Research Working Paper. Cambridge, 17787. http://www.nber.org/chapters/c12632.pdf

Romer, C. D. and D. H. Romer (2010). The Macroeconomic Effects of Tax Changes: Estimates Based on a New Measure of Fiscal Shocks. American Economic Review. 100. ss. 763-801.

Romer, C. D. and J. Bernstein (2009). The Job Impact of the American Recovery and Reinvestment Plan. Council of Economic Advisers. January 10.

Romer, C. D. and J. Bernstein (2009). The Job Impact of the American Recovery and Reinvestment Plan. Council of Economic Advisers. January 10.

Romer, Christina and David Romer, 2008, “The Macroeconomic Effects of Tax Changes: Estimates Based on a New Measure of Fiscal Shocks," University of California, Berkeley, mimeo, November.

Shapiro, M., and Watson, M. (1988). Sources of business cycle fluctuations, in S. Fisher (ed.). NBER Macroeconomic Annual, 3, 111-156.

Shoag, D. (2010). The İmpact of Government Spending Shocks: Evidence on the Multiplier from State Pension Plan Returns, Unpublished paper, Harvard University.

Sims, C. A. (1986). Are forecasting models usable for policy analysis? Federal Reserve Bank of Minneapolis Quarterly Review, 2-16.

Solow, Robert M. (1956); “A Contribution to the Theory of Economic Growth,” Quartely Journal of Economics. 70 (1): 65-94. doi: 10.2307/1884513

View Article: DOI: http://dx.doi.org/10.2307/1884513

Temiz, D. (2008). Türkiye’de Vergi Gelirleri ve Ekonomik Büyüme İliskisi 1960 - 2006 Dönemi, 2.Ulusal İktisat Kongresi Sunumu, İzmir.

Wilson, D. J. (2012). Fiscal spending multipliers: evidence from the 2009 American Recovery and Reinvestment Act. American Economic Journal: Economic Policy.

Yuan, M. and W. Li (2000). Dynamic employment and hours effects of government spending shocks. Journal of Economic Dynamics and Control. 24(8). 1233-1263. doi: 10.1016/S0165-1889(99)00007-X

View Article: DOI: http://dx.doi.org/10.1016/S0165-1889(99)00007-X

Zeng J. and Du H. (2003). "Allocation of Tax Revenue and Growth Effects of Taxation", http://www.vanderbilt.edu/econ/faculty/Wooders/APET/Pet2004/Papers/Allocation\% $20 \mathrm{of} \% 20 \mathrm{tax} \% 20$ revenue.pdf

Zubairy, S. (2009). On fiscal multipliers: estimates from a medium scale DSGE model. Manuscript, Duke University. 